\title{
Journal of Science and Science Education
}

http://jppipa.unram.ac.id/index.php/jossed/index

\section{The Effect of Guided Inquiry Learning Model on Chemistry Learning Outcomes}

\author{
Siti Hasanah ${ }^{1}$, Agus Abhi Purwoko ${ }^{1}$, Aliefman Hakim ${ }^{1 *}$ \\ ${ }^{1}$ Master of Science Education Study Program, Graduate University of Mataram, Mataram, Indonesia.
}

\section{Article Info}

Received : April, $12^{\text {th }} 2020$

Revised : September, $10^{\text {th }} 2020$

Accepted: October, $7^{\text {th }} 2020$

\begin{abstract}
Teachers and students still dominate the learning process at SMAN 1 Lingsar are even less active. This study aimed to determine the effect of the Guided Inquiry learning model on students' chemistry learning outcomes. This study used quasi-experimental research (quasi-experimental) with a nonequivalent control group design pre-test-post-test design. The population in this study were all Class XI IPA SMAN 1 Lingsar. The sampling technique used a quota sampling technique. The sample consisted of 2 classes, namely class XI MIA 1 as the experimental class and class XI MIA 4 as the control class. The instruments in this study were 3 , namely: RPP, LKPD, and Tests. The test is carried out at the beginning of the meeting (pre-test) and the end of the session (posttest). The resulting data were tested using the ANCOVA test. The results showed differences in chemistry learning outcomes for students who took the guided inquiry learning model with those who took the conventional learning model. The results of statistical tests obtained a significance value of the learning model of 0.011 . So because the amount of the Sig value is less than $0.05, \mathrm{H} 0$ is rejected. It means a linear relationship between them with the average chemistry learning outcomes in the class that received the guided inquiry empowerment model higher than the control group. Furthermore, the covariance proved also to support the improvement of students' chemistry learning outcomes with a significance level of 0.000 . It means that there is a linear relationship between the covariance and the dependent variable.
\end{abstract}

Keywords: Learning model; guided inquiry; learning outcomes.

Citation: Hasanah, S., Purwoko, A.A., Hakim, A. (2019). The Effect of Guided Inquiry Learning Model on Chemistry Learning Outcomes. Journal of Science and Science Education (JoSSEd), 1(1), 15-20.

\section{Introduction}

In essence, science can be viewed as a product and as a process. Science is a method of systematically finding out about nature to master knowledge, facts, concepts, principles, discovery, and scientific attitude [1]. Science also refers to the structure of experience that a person acquires through these methods. In other words, science is a way of obtaining knowledge with specific methods [2].

Chemistry plays an essential role in the development of other sciences in the field of agriculture [3]. For example, chemistry contributes to discovering fertilizers and pesticides that are proven to increase agricultural production. The rapid development of the food and beverage industry cannot be separated from the contribution of chemistry and household materials such as detergents, soap, toothpaste, and others, which are products of the chemical industry [4]. An interesting problem, although chemistry provides many benefits in everyday life [5], many facts show that students find chemistry challenging to learn [6]. It is because chemistry subjects are filled with formulas and symbols.

The observations at SMAN 1 Lingsar, West Lombok Regency, show that chemistry learning is still teacher-centered. The delivery of subject matter tends to be dominated by the lecture method. Students are less active in the learning process to build and discover for themselves through interaction with their 
environment. Students only memorize facts from books and not from finding and building their knowledge. Students find it difficult to understand academic concepts as taught so far, using something abstract with the lecture method. Learning that is oriented towards the target of mastery of the material is proven only to lead students to remember the subject matter in a relatively short time. Still, often children do not understand and know in-depth. The knowledge gained in the only memorization causes the child to forget easily, thus failing to equip the child to solve problems quickly. Besides, the lack of interaction between teachers and students causes learning to be less enjoyable, causing boredom and sleepiness when the learning process takes place. It does not give students room to think because the learning process is only teacher-centered.

The teacher does not provide question exercises so that some activities can minimize students' boredom during the learning process. In the absence of actions or activities such as group discussions, conducting experiments (practicum), students carry out their activities without listening to what the teacher explains in front of the class, such as chatting with classmates, sleeping, playing cellphones, etc.

This has been a problem so far, so researchers want to apply a learning model that focuses more on the importance of student activity (student-centered). Inaccuracy in using the learning model will cause boredom for students in receiving the material presented so that the material cannot be understood, causing them to become bored. Besides, many students cannot understand a concept in learning, especially chemistry lessons. This condition causes a learning model that can trigger students to be more active in improving their thinking skills, cooperation, and solving problems in life [7]. The learning model is one of the essential components of the learning process [8]. No matter how good the material is, it will not work optimally without the right method and can even experience failure.

Based on the above assumptions, the researcher wants to offer an alternative action to solve the existing problem by applying other learning models that prioritize student activity and develop their potential to the fullest. The learning model in question is a guided inquiry learning model.

One model of student-centered learning is inquiry [9]. The inquiry is a learning model that stimulates, teaches, and invites students to think critically, analytically, and systematically to find answers independently of the various problems raised [10]. This model is learning that requires the active involvement of students to investigate and seek active thought processes. Students who have a lot of activity in this strategy are students through mental processes. Students have the flexibility and freedom to explore all their abilities without being overwhelmed [11].

An inquiry-based learning model can optimize the direct experience of students in the learning process. Inquiry-based learning provides more opportunities for students to learn and work through the inquiry process as a scientist or researcher works [12]. Inquiry-based learning provides more opportunities for students to have the opportunity to learn how to find facts, concepts, and principles through their own direct experience [13].

Based on the above background, the researcher is motivated to research the effect of the guided injury learning model on the chemistry learning outcomes of students of SMAN 1 Lingsar.

\section{Method}

The research was conducted at SMAN 1 Lingsar. It used quasi-experimental research with a nonequivalent control group design pre-test-post-test design. The population was all Class XI IPA SMAN 1 Lingsar, and the sampling technique used a quota sampling technique. The sample consists of 2 classes, namely class XI MIA 1 as the experimental class and class XI MIA 4 as the control class. The instruments in this study were 3 , namely: RPP, LKPD, and Tests. The test uses multiple-choice questions with five answer choices consisting of 20 questions. The test is carried out at the beginning of the meeting (pre-test) and the end of the session (posttest). The resulting data will then be tested for ANCOVA.

\section{Result and Discussion}

Based on the Anacova type I model's analysis, the learning model's effect is an independent variable on students' final chemistry learning outcomes (posttest) as the dependent variable. For more details, see table 1:

Table 1: Anacova Type I Analysis for Chemistry Learning Outcomes Variables (Post-test)

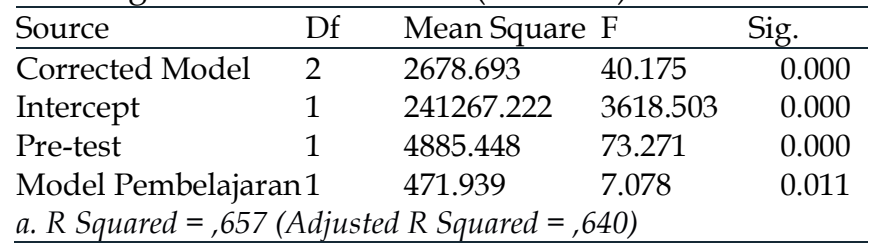

Based on table 1, the results show that the significance level of the learning model is 0.011 . So because of the value of Sig. $<0.05, \mathrm{H} 0$ is rejected. It means a linear relationship between the learning model 
and chemistry learning outcomes (Post-test). There are differences in chemistry learning outcomes for students who take guided inquiry learning models with conventional learning models. Based on the descriptive table, the average chemistry learning outcomes in the class that received recommended inquiry empowerment model treatment $(\mathrm{M}=77.17 ; \mathrm{SD}=$ 13.041) were higher than those of the control group ( $M$ $=69.09 ; \mathrm{SD}=13.241)$. For more details, see table 2 :

Table 2: Descriptive Statistics Dependent Variable: Chemistry Learning Outcomes (Post-test)

\begin{tabular}{llll}
\hline Learning model & Mean & \multicolumn{2}{l}{$\begin{array}{l}\text { Std. } \\
\text { Deviation }\end{array}$} \\
\hline Guided Inquiry Learning Model & 77.17 & 13.041 & 23 \\
Conventional Learning Model & 69.09 & 13.241 & 22 \\
Total & 73.22 & 13.616 & 45 \\
\hline
\end{tabular}

Furthermore, to determine the pre-test (pre-test) effect as a covariance on chemistry learning outcomes (posttest) as the dependent variable, testing was carried out using the Anacova type III analysis model. This test is Anakova Type III to eliminate the influence of the learning model. Based on data processing through SPSS 24 , the results are as shown in table 3 :

Table 3: Anacova Type III Analysis for Chemistry Learning Outcomes Variables (Post-test)

\begin{tabular}{lcccc}
\hline Source & Df & $\begin{array}{l}\text { Mean } \\
\text { Square }\end{array}$ & F & Sig. \\
\hline Corrected Model & 2 & 2678.693 & 40.175 & 0.000 \\
Intercept & 1 & 2882.192 & 43.227 & 0.000 \\
Pre-test & 1 & 4622.732 & 69.331 & 0,000 \\
Learning model & 1 & 471.939 & 7.078 & 0.011 \\
a. $R$ Squared $=0.657$ (Adjusted $R$ Squared $=0.640)$ & \\
\hline
\end{tabular}

Based on the table data, the result shows that the pre-test's significance as a covariance is 0.000 . So because of the value of $\mathrm{Sig}<0.05, \mathrm{H} 0$ is rejected. It means a linear relationship between the initial chemistry learning outcomes (Pre-test) and the chemistry learning outcomes (Post-test). This statement indicates that the ANCOVA assumption has been fulfilled.

Furthermore, to determine the effect of differences in learning models as independent variables and pre-test as a covariate on chemistry learning outcomes (Post-test) as the dependent variable simultaneously, it can be seen from the significant number in the corrected model section. It can be seen that the significant figure for the corrected model is 0.000 . Because the significance value $<0.05, \mathrm{H} 0$ is rejected, so it can be concluded that simultaneously there is an effect of the learning model and initial knowledge (Pre-test) on chemistry learning outcomes (Post-test).
Based on the descriptive table that the average chemistry learning outcomes in the class that received guided inquiry empowerment model treatment $(\mathrm{M}=$ 77.17; $\mathrm{SD}=13.041$ ) were higher than the control group $(\mathrm{M}=69.09$; $\mathrm{SD}=13.241)$. Therefore, guided inquiry learning methods have succeeded in improving student learning outcomes in chemistry learning at SMA Negeri 1 Lingsar, West Lombok Regency, West Nusa Tenggara Province.

The pre-test effect as a covariance is also proven to support the increase in chemistry learning outcomes with a significant number of 0.000 . So because of the value of Sig. < 0.05, H0 is rejected. It means a linear relationship between initial knowledge (pre-test) and final chemistry learning outcomes (posttest). This statement indicates that the ANCOVA assumption has been fulfilled. Furthermore, the significance figure for the corrected model is 0.000 . Because the significance value $<0.05, \mathrm{H} 0$ is rejected, so it can be concluded that simultaneously there is an effect of the learning model and initial knowledge (Pre-test) on chemistry learning outcomes (Post-test).

The average value shows an increase in the control class's student learning outcomes by 69.09 and the experimental class by 77.17. The experimental class students had a higher average score than the control class. The experimental class's high posttest results are because the experimental class is taught with a guided inquiry learning model. Guided inquiry learning involves students actively in learning. Simultaneously, conventional learning involves more teachers than students, so that students only follow what the teacher trains without being actively involved in finding concepts and facts.

Cognitive learning outcomes are influenced by the method used by the teacher [14]. This study indicates that the achievement of student learning outcomes taught by guided inquiry learning methods provides more optimal results than students learning with conventional methods. Activeness in discussions to solve problems through observation will foster high learning motivation in students and will ultimately affect learning outcomes [15]. Students who find their own concepts through guidance by the teacher will have a long-term memory because students are actively involved in finding their own concepts.

Furthermore, to determine the pre-test (pre-test) effect as a covariance on chemistry learning outcomes (posttest) as the dependent variable, testing was carried out using the ANCOVA type III analysis model. This ANCOVA Type III test determines the effect of differences in learning models as independent variables and pre-test as a covariate on chemistry learning outcomes (Post-test) as the dependent variable simultaneously. It can be seen from the significant 
number in the corrected model section. It can be seen that the significant figure for the corrected model is 0.000 . Because the significance value $<0.05, \mathrm{H} 0$ is rejected, so it can be concluded that simultaneously there is an effect of the learning model and initial knowledge (Pre-test) on chemistry learning outcomes (Post-test). Based on the data analysis, the result shows that the significant number of pre-test (pre-test) as a covariance is 0.000 . So because of the value of Sig. $<0.05, \mathrm{H} 0$ is rejected. It means that there is a linear relationship between pre-test and chemistry learning outcomes (Post-test). This statement indicates that the ANCOVA assumption has been fulfilled.

The learning process with the guided inquiry model in the experimental class is not only through providing material but also accompanied by practicum. Students can observe objects directly. The guided inquiry process stages make students more active in looking for material information to be studied so that the material becomes easier to find [16]. In the experimental class, the learning process begins with building students' initial knowledge with the teacher providing problem formulations in the LKPD. The students will solve the problem formulation through observation, which is then linked to the theory collected from various sources, through the questions listed in the LKPD and through group discussions guided by the teacher. Based on the idea that has been collected, students are guided by the teacher to formulate hypotheses by linking the theory they get with the problem formulations they have created.

Before students carry out the data collection process, students must formulate the variables that exist in the LKPD. The formulation of this variable serves to provide an overview and limitations of what students will observe. However, at the time of the formulation of the variables, several groups experienced difficulties. The teacher provided guidance and direction to each group that had difficulty determining the correct research variables. After the data collection process, students and their respective groups discuss what they have observed by filling in some of the questions that the teacher provides in the LKPD sheet. The teacher guides students who have difficulty or do not understand the questions given. The learning process with discussions by each group makes students active in learning activities. Through teacher guidance, they can find their concepts through the learning process that has been implemented. In guided inquiry learning, students are involved directly and maximally to seek and find their answers to their problems.

Interest in problems and high curiosity causes students to be motivated to be actively involved in the learning process at each stage of guided inquiry to answer the students' issues themselves. The answer obtained is then formulated into a conclusion that is used to build theory. Theory or information obtained from direct student involvement or, in other words, as a result of this student's findings can be recorded longer in students' memory. This can be seen in the post-test results of students in the experimental class, which are higher than the control class post-test results. It means that the guided inquiry learning model can improve student learning outcomes. This guided inquiry learning model can help students understand and master the buffer solution material through direct student observation through a practicum.

In the control class, students are taught using conventional learning. SMAN 1 Lingsar teachers generally give conventional learning in question to students in the learning process, namely the lecture method. The lecture method is one of the teachercentered methods. Students in the control class only listen to information through the teacher's explanation without inviting them to develop the information obtained. Students tend to listen and take notes on what the teacher says, but some students do not take notes and are busy doing other activities such as chatting with friends to less interaction between teachers and students in a class.

The learning process using the lecture method tends to make students passive. This can be seen when the teacher asks questions about the material that has been delivered. Only two students answer the teacher's questions while the others stay silent without trying to answer the questions the teacher gives. The teacher also wrote the practice questions on the blackboard and asked the students to come forward to solve the questions. Still, only a few students were enthusiastic about looking for the answers, while others were just silent and chatting with their friends. Students also do not respond when the teacher asks for material that has not been understood. Teachers find it difficult to know how students understand the concepts they should know and make teachers assume that they have mastered the material that has been taught.

Individual learning outcomes are influenced by student learning. Several factors can affect student learning besides the learning model, namely student learning hours, where the learning hours are at the last hour of knowledge. It causes students to be less able to concentrate on discussing with their respective groups.

In control class learning, students are given the task of looking for material independently by the teacher using the lecture method so that teachers and students more dominate learning need to follow what the teacher asks. The concepts are given directly by students and then given reinforcement, not obtained through the discovery process. The concepts obtained 
by students are permanent and stored in students' short-term memory. The difference in learning methods given to these students causes differences in the learning process results carried out. This short-term memory is reflected in the control class students' learning outcomes, who are still much below the KKM. The number of students in the experimental class under the KKM is three students, while the number of students under the KKM in the control class is 8 students. The knowledge obtained by inquiry shows some goodness, namely, knowledge lasts long, improves student reasoning and the ability to think freely, and trains students' cognitive skills to find and solve problems independently [17].

In learning activities, a guided inquiry has been shown to improve student learning outcomes. Through guided inquiry activities in their learning, students are conditioned to construct (arrange) the information they get so that knowledge is obtained due to their learning. According to the constructivist learning paradigm, it emphasizes students' skills in finding or answering problems and questions through observations, experiments, or other activities [18].

ANCOVA test shows that there is a significant effect of learning methods on student learning outcomes. The test shows that students who learn using guided inquiry methods have higher cognitive learning outcomes than students who learn using conventional methods. Further analysis shows that there is a difference in the average value of student learning outcomes who are taught with the guided inquiry method higher than the conventional method.

Cognitive learning outcomes consist of remembering, understanding, applying, analyzing, and creating. Learning using the guided inquiry method starts with identifying and formulating problems and answering these questions (formulating hypotheses), proven through group experiments. Through questions, students are trained to make available observations, determine predictions, make it easy for students to remember and understand the material being studied, and relate it to real life, making it easier to apply it again. Before testing the hypothesis, students will also be required to analyze supporting data, test hypotheses and make conclusions, and present them, so that students' ability to analyze will increase. After students pass these stages, students will be able to improve their ability to create. So that in an effort to instill the concept, it is not enough to just lecture. Learning will be more meaningful if students are given the opportunity to know and be actively involved in discovering concepts from facts seen from the environment with teacher guidance [19].

Affective assessment in research includes character and social skills, namely responsibility, honesty, activeness inside and outside the presentation, and attention to other groups' presentations. In the experimental class, students have good interactions between their respective groups, are optimistic and have persistence in learning, have responsibilities, and enjoy learning challenges. The character of this attitude can be seen from students' responsibility in working on LKPD, honesty in writing data, the enthusiasm of students in group discussions, and presentation discussions. In the control class, some students are less responsible for their duties, less active in discussions, and less paying attention to other groups' presentations. This is because students do not have learning motivation and responsibility, so learning difficulties are considered a burden. Besides, students who are less challenged are also caused by students who are not given varied, interesting, and meaningful learning. Students feel less enthusiastic in learning because the method used is only the lecture method. Differences in attitudes and character of students of the two classes will cause differences in learning outcomes. The students not only learn the concepts in guided inquiry learning, but also learn about self-direction, responsibility, and communication to allow students to assimilate and accommodate the information [20].

The advantages of the guided inquiry method are: (1) increasing student involvement actively in obtaining and processing learning acquisition, (2) directing students as lifelong learners, (3) reducing dependence on teachers as the only source of information used by students, and (4) train students to explore/utilize their environment as a source of information that will never be completely explored.

\section{Conclusion}

This study concludes that there are differences in chemistry learning outcomes for students who take guided inquiry learning models with conventional learning models.

\section{Acknowledgments}

Thank you very much for my supervisor, Prof. Drs. Agus Abhi Purwoko, M.Sc., Ph.D. and Dr. Aliefman Hakim, M.Si, who always guided me in completing this research. We would also like to thank the Master of Science Education Study Program who always helps complete administration research to conduct this research.

\section{References}

[1] Osman, K. 2012. Primary science: Knowing about the world through science process skills. Asian 
Social Science, 8(16), 1-7.

https://doi.org/10.5539/ass.v8n16p1

[2] Khaeruman, K., Nurhidayati, S. N., \& Rahayu, S. 2014. Efektifitas Penerapan Model Pembelajaran Problem Solving Dengan Context-Rich Problems Pada Materi Pokok Termokimia Dalam Meningkatkan Hasil Belajar Siswa Dan Kemampuan Berpikir Kritis. Prisma Sains: Jurnal Pengkajian Ilmu Dan Pembelajaran Matematika Dan IPA IKIP Mataram, 2(1), 18. https://doi.org/10.33394/j-ps.v2i1.1051

[3] Dom, M., \& Pandi, J. 2011. What can analytical chemistry contribute in agricultural systems research towards achieving PNG vision 2050? UNESCO International Year of Chemistry, Conference at the University of Papua New Guinea, (June 2015), 113.

[4] Bosiu, T., Chinanga, F., Das Nair, R., Mondliwa, P., Phiri, M., \& Ziba, F. 2018. Growth and Development in the Cosmetics, Soaps and Detergents Regional Value Chains: South Africa and Zambia. SSRN Electronic Journal. https://doi.org/10.2139/ssrn.3103590

[5] Chun, W., \& Foos, J. 2010. Making Chemistry Fun to Learn. Lit Inf Comput Educ J., 1(1), 1-7. https://doi.org/10.1038/jid.2014.371

[6] Cardellini, L. 2012. Chemistry: Why the Subject is Difficult? Educación Química, 23, 305-310. https://doi.org/10.1016/s0187-893x(17)30158-1

[7] Khasanah, U., \& Astuti, D. 2018. International Journal of Active Learning Developing Mathematics Learning Model of Thinking Empowerment by Question ( TEQ ) with TAI Setting to Improve Students ' Metacognition Ability. International Journal of Active Learning, 3(2), 80-85. Retrieved from http://journal.unnes.ac.id/nju/index.php/ijal

[8] Nugraha, I. S., \& Suherdi, D. 2017. Scientific Approach: an English Learning-Teaching (Elt) Approach in the 2013 Curriculum. Journal of English and Education, 5(2), 112-119. Retrieved from http://ejournal.upi.edu/index.php/L-

E/article/view/9941

[9] Hesson, M., \& Shad, K. F. 2007. A Student-Centered Learning Model. American Journal of Applied Sciences, 4(9), 628-636.

[10]Tusriyanto, Nadiroh, Japar, Wahyudi, A., Aminudin, K., \& Widayati, E. 2019. Improved of Critical Thinking Skills and Social Skills for Students Through Inquiry Learning (Guided Enquiry) Based Literacy on the Subject of Social Sciences in Class V. OPCION JOURNAL, 20(9), 1689-1699.

https://doi.org/10.1017/CBO9781107415324.004

[11] Hartono, R. 2013. Ragam Model Mengajar Yang mudah Diterima Oleh Murid. Jogjakarta: Diva Press.

[12] Laksana, D. N. L., Dasna, I. W., \& Degeng, I. N. S. 2019. The effects of inquiry-based learning and learning styles on primary school students' conceptual understanding in multimedia learning environment. Journal of Baltic Science Education, 18(1), 51-62. https://doi.org/10.33225/ibse/19.18.51

[13] Jufri, A. W. 2013. Belajar dan Pembelajaran Sains (P. R. Cipta., ed.). Banding.

[14]Shi, Y., Ma, Y., MacLeod, J., \& Yang, H. H. 2020. College students' cognitive learning outcomes in flipped classroom instruction: a meta-analysis of the empirical literature. Journal of Computers in Education, 7(1), 79-103. https://doi.org/10.1007/s40692-019-00142-8

[15] Fukuzawa, S., Boyd, C., \& Cahn, J. 2017. Student Motivation in Response to Problem-based Learning. Collected Essays on Learning and Teaching, 10 , 175-188. https://doi.org/10.22329/celt.v10i0.4748

[16] Sukma, M. C., \& Ibrahim, M. 2016. Developing materials for active learning of guided inquiryintegrated bowling campus on the topic of sense of hearing and sonar system of living organism. Jurnal Pendidikan IPA Indonesia, 5(2), 256-260. https://doi.org/10.15294/jpii.v5i2.5981

[17] Martaida, T., Bukit, N., \& Ginting, E. M. 2017. The Effect of Discovery Learning Model on Student's Critical Thinking and Cognitive Ability in Junior High School. IOSR Journal of Research $\mathcal{E}$ Method in Education, 7(6), 1-8. https://doi.org/10.9790/7388$\underline{0706010108}$

[18] Faradilla, M., Hasan, M., \& Sulastri. 2018. The effectiveness of guided inquiry-based student worksheets on students' generic science skills. Journal of Physics: Conference Series, 1088. https://doi.org/10.1088/17426596/1088/1/012106

[19] Darling-Hammond, L., Flook, L., Cook-Harvey, C., Barron, B., \& Osher, D. 2020. Implications for educational practice of the science of learning and development. Applied Developmental Science, 24(2), 97-140. https://doi.org/10.1080/10888691.2018.1537791

[20] Schuster, D., Cobern, W. W., Adams, B. A. J., Undreiu, A., \& Pleasants, B. 2018. Learning of Core Disciplinary Ideas: Efficacy Comparison of Two Contrasting Modes of Science Instruction. In Research in Science Education (Vol. 48). https://doi.org/10.1007/s11165-016-9573-3 